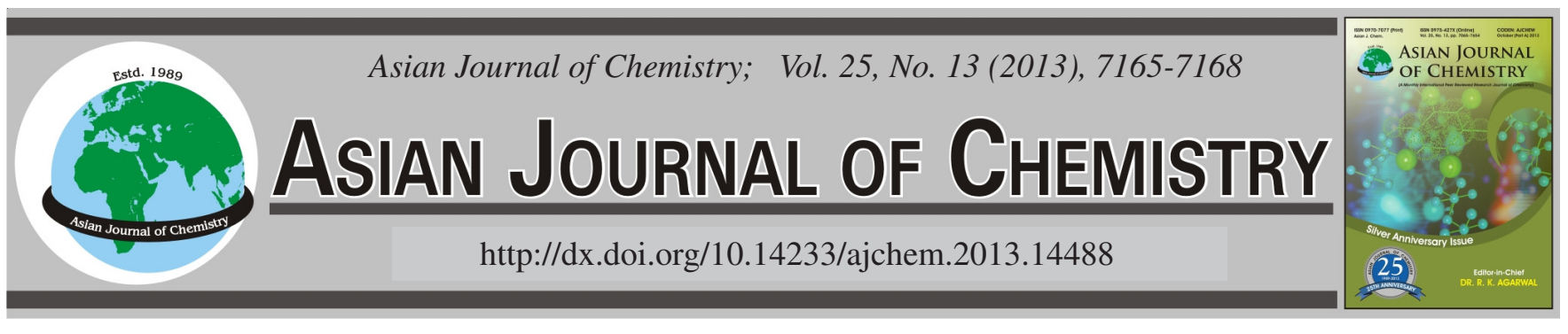

\title{
Adsorption Behaviour of D201×4 Resin for Platinum(IV)
}

\author{
J.J. Mo ${ }^{1, *}$, L.L. $\mathrm{PI}^{2}$ and J. YU ${ }^{1}$
}

${ }^{1}$ Department of Chemistry, Lishui University, No 1. Xueyuan Road, Lishui 323000, P.R. China

${ }^{2}$ School of Food and Biotechnology, Zhejiang Gongshang University, No 149. Jiaogong Road, Hangzhou 310012, P.R. China

*Corresponding author: Fax: +98 21 22222512; Tel: +98 21 22262561; E-mail: mjj127@126.com; jianjunmo@yeah.net

(Received: 25 August 2012;

Accepted: 19 June 2013)

AJC-13664

\begin{abstract}
The adsorption behaviour of $\mathrm{D} 201 \times 4$ resin for $\mathrm{Pt}(\mathrm{IV})$ were investigated. The influences of medium $\mathrm{pH}$, temperature, retention time on adsorption process are studied. $\mathrm{Pt}(\mathrm{IV})$ was quantitatively adsorbed by $\mathrm{D} 201 \times 4$ resin in the medium of $\mathrm{pH}=3.47$. The statically saturated adsorption capacity is $567.5 \mathrm{mg} / \mathrm{g}$. Pt(IV) adsorbed on D201 $\times 4$ resin can be eluted by $0.1-2.0 \mathrm{~mol} / \mathrm{L} \mathrm{NaOH}$. The rate constant is $\mathrm{k}_{298}=$ $9.13 \times 10^{-5} \mathrm{~s}^{-1}$. The Pt(IV) adsorption process on D201 $\times 4$ resin obeys the Freundlich isotherm. The adsorption parameters of thermodynamic are as follows: enthalpy change $(\Delta \mathrm{H})=1.65 \mathrm{KJ} / \mathrm{mol}$, Gibbs free energy change $(\Delta \mathrm{G})=-8.65 \mathrm{KJ} / \mathrm{mol}$ and entropy change $(\Delta \mathrm{S})=34.57 \mathrm{~J} /$ $(\mathrm{mol} \mathrm{K})$. The apparent activation energy $\left(\mathrm{E}_{\mathrm{a}}\right)$ is $11.93 \mathrm{KJ} / \mathrm{mol}$. The coordination molar ratio of the functional group of $\mathrm{D} 201 \times 4 \mathrm{resin}$ to $\mathrm{Pt}(\mathrm{IV})$ was $1: 1$.
\end{abstract}

Key Words: D201×4 resin, Platinum, Adsorption, Behaviour.

\section{INTRODUCTION}

In recent years, noble metals have not only been used as adornment and currency, they have been extensively applied in micro-electronics, aviation, atomic energy, chemical industry, environmental protection, military industry, medicine, etc. Platinum is characterized by corrosion resistance, steady thermoelectricity and excellent catalysis. With the rapid development of technology, platinum is increasingly required, which brings about the extensive exploration of its separation and refinement. Its traditional methods of separation and deposition have undergone several challenges ${ }^{1-9}$. Many efforts have been made to separate and concentrate certain metals by using ion exchange resin ${ }^{10-16}$.

The adsorption of platinum has been investigated at present, but most of the adsorption materials have relative low adsorption capacity ${ }^{17-19}$. In this article, the capability and mechanism of platinum absorbed by the D201 $\times 4$ resins in $\mathrm{CH}_{3} \mathrm{COOH}-\mathrm{CH}_{3} \mathrm{COONa}$ medium are studied. A series of important parameters have been obtained, which supply the theory of platinum enriched and separated by the D201×4 resins.

\section{EXPERIMENTAL}

D201×4 resin (provided by Nankai university, activated before use). Standard solution of platinum(IV) prepared from $\mathrm{K}_{2} \mathrm{PtCl}_{6}$. Buffer solution with $\mathrm{pH}$ 2.63-5.73 prepared from acetic acid and sodium acetate $\left(\mathrm{CH}_{3} \mathrm{COOH}-\mathrm{CH}_{3} \mathrm{COONa}\right)$. The other reagents were of $\mathrm{AR}$ grade.
723 spectrophotometer (the Third Analysis Instrument Factory of Shanghai); SartoriusPB-20 pH meter (Germany Sartorius Stock Company); SHZ-B temperature constant shaking machine (Shanghai Yuejin Medical Treatment Machine Factory); Perkin-Elmer683 FT-IR (American Nicolet Instrument Company).

Method: A solution containing lesser than $75 \mathrm{~g}$ of $\mathrm{Pt}(\mathrm{IV})$ was accurately added into a $25 \mathrm{~mL}$ colorimetric tube and then $5 \mathrm{~mL}$ of $\mathrm{HCl}$ solution and $5 \mathrm{~mL} 25 \% \mathrm{SnCl}_{2}$ solution were added. After the addition of redistill water to the mark of the colorimetric tube, the absorbency was determined in a $1 \mathrm{~cm}$ colormetric vessel at a wavelength of $403 \mathrm{~nm}$ and compared with blank test.

\section{General procedure}

Adsorption equilibrium experiment: A desired amount of treated resin was weighed and added into a conical flask; then a desired volume of buffer solution with $\mathrm{pH}=3.47$ was added. After $24 \mathrm{~h}$, a required amount of standard solution of $\mathrm{Pt}(\mathrm{IV})$ was added ${ }^{20,21}$. The flask was shaken in a shaker at constant temperature. The upper layer of clear solution was taken for analysis until the adsorption equilibrium was reached. The distribution coefficient (D) was calculated as follows:

$$
\mathrm{D}=\frac{\mathrm{Q}_{\mathrm{R}}}{\rho_{\mathrm{e}}}
$$

where $Q_{R}=\left(\rho_{o}-\rho_{e}\right) V / m ; \rho_{o}$ is the initial concentration of metal ion in solution, $\mathrm{mg} / \mathrm{mL} ; \rho_{\mathrm{e}}$ is the equilibrium concentration of 
metal ion in solution, $\mathrm{mg} / \mathrm{mL} ; \mathrm{V}$ is the total volume of solution, $\mathrm{mL} ; \mathrm{m}$ is the mass of resin, $\mathrm{g}$.

Elution test: $15 \mathrm{mg}$ of resin was added into a mixed solution composed of $\mathrm{pH}=3.47$ buffer solution and desired amount of standard solution of Pt(IV). After the equilibrium was reached, the concentration of Pt(IV) in the aqueous phase was determined and then the adsorption capacity of the resin for $\mathrm{Pt}(\mathrm{IV})$ was obtained. The resin that has adsorbed $\mathrm{Pt}(\mathrm{IV})$ was separated from the aqueous phase and washed three times with $\mathrm{pH}=3.47$ buffer solution and the eluant was added to the resin. After the elution equilibrium was reached, the concentration of $\mathrm{Pt}(\mathrm{IV})$ in corresponding aqueous was determined and then the percentage of elution was obtained.

\section{RESULTS AND DISCUSSION}

Influence of $\mathrm{pH}$ on the distribution coefficient (D): The test was carried out according to the above-mentioned method. The influence of $\mathrm{pH}$ on the adsorption behaviour of $\mathrm{D} 201 \times 4$ resin for Pt(IV) is shown in Fig. 1. The results show that the distribution coefficient (D) was the highest at $\mathrm{pH}=3.47$. Thus, all the following experiments were carried out at $\mathrm{pH}=3.47$.

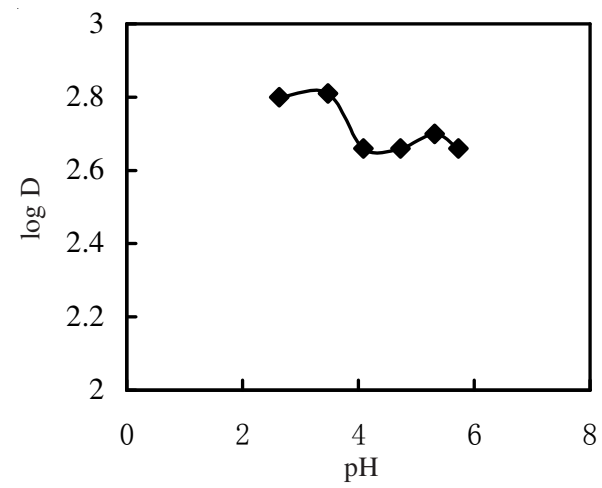

Fig. 1. Influence of $\mathrm{pH}$ on distribution coefficient. Resin $10 \mathrm{mg}, 298 \mathrm{~K}$, $\rho_{0}=333 \mathrm{mg} / \mathrm{L}$

Determination of $\mathbf{t}^{\prime}{ }_{1 / 2}: 20 \mathrm{mg}$ of resin was weighted accurately. Under the experimental condition shown in Fig. 2, the upper layer clear solution was taken out of the total $40 \mathrm{~mL}$ solution at intervals for determining their concentrations, respectively. After their volume was corrected, a series of data was obtained and plotted as shown in Fig. 2. The result shows that $\mathrm{t}_{1 / 2}^{\prime}$ is equal to $4 \mathrm{~h}$. Here, $\mathrm{t}_{1 / 2}^{\prime}$ is the time required to reach $50 \%$ adsorption.

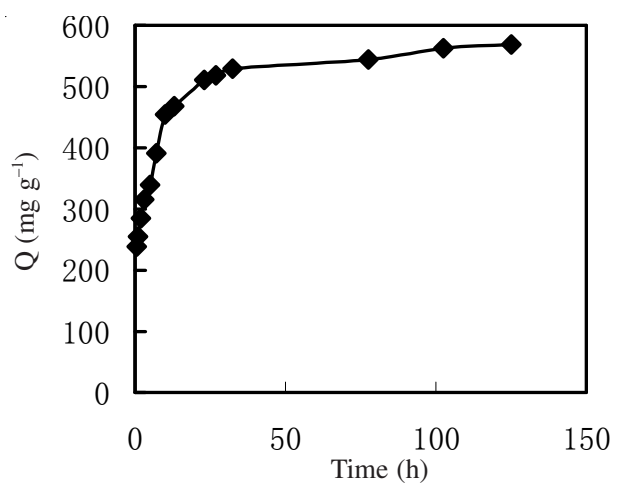

Fig. 2. Sorption rate curve of D201×4resin for Pt. $\mathrm{pH}=3.47,298 \mathrm{~K}$, $\mathrm{r}_{0}=300 \mathrm{mg} / \mathrm{L}$
Determination of the adsorption rate constant and apparent activation energy of $\mathrm{D} 201 \times 4$ resin for $\mathrm{Pt}(\mathrm{IV})$ : Four portions of $20 \mathrm{mg}$ of resin were weighted accurately and put into conical flasks individually. The experiment was carried out using the above-mentioned method at 291, 298, 308 and $318 \mathrm{~K}$. According to the experimental condition shown in Fig. 3, the upper layer clear solution was taken out of the 40 $\mathrm{mL}$ solution at intervals for determining their concentrations, respectively. After their concentration was kept constant and the volume was corrected, a series of data was obtained. According to the Brykina method ${ }^{22}$, the adsorption rate constant $\mathrm{k}$ can be calculated from $-\mathrm{ln}(1-\mathrm{F})=\mathrm{kt}$, where $\mathrm{F}=$ $\mathrm{Q}_{\mathrm{t}} / \mathrm{Q}_{\infty}$ and $\mathrm{Q}_{\mathrm{t}}$ and $\mathrm{Q}_{\infty}$ are the adsorption amounts at a certain time at equilibrium, respectively. The slope of straight line, which is made by plotting $-\ln (1-\mathrm{F})$ versus $\mathrm{t}$ (Fig. 3), yields the adsorption rate constant $\mathrm{k}$ and thus, the values of $\mathrm{k}$ at 291 , 298, 308 and $318 \mathrm{~K}$ were obtained: $\mathrm{k}_{318}=12.56 \times 10^{-5} \mathrm{~s}^{-1}, \mathrm{k}_{308}$ $=10.34 \times 10-5 \mathrm{~s}^{-1}, \mathrm{k}_{298}=9.13 \times 10^{-5} \mathrm{~s}^{-1}, \mathrm{k}_{291}=7.85 \times 10^{-5} \mathrm{~s}^{-1}$. According to the Boyd liquid film spreading equation ${ }^{23}$, it can be known from the linear relationship between $-\ln (1-\mathrm{F})$ and $t$ that liquid film spreading is the predominant step of the adsorption process.

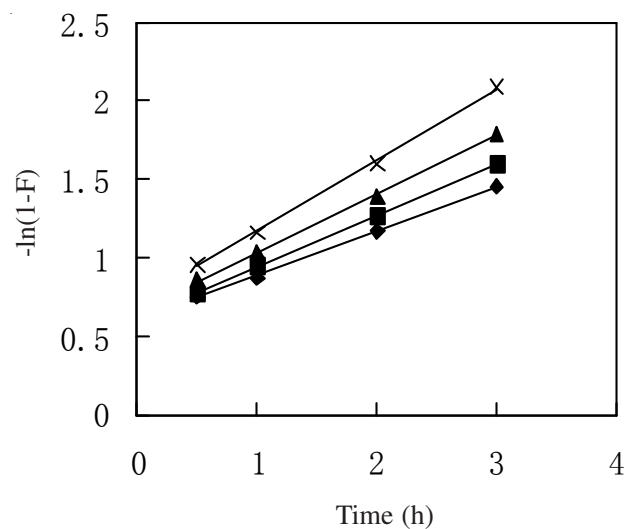

Fig. 3. Determination of rate content of D201 $\times 4$ resin for Pt. $\rho_{0}=300 \mathrm{mg} / \mathrm{L}$, $\mathrm{pH}=3.47$

By plotting log k against 1/T (Fig. 4), the slope of straight line $\mathrm{K}_{\text {slop }}=-0.623$. The correlation coefficient $\mathrm{r}=-0.9977$ was achieved. According to Arrhenius equation:

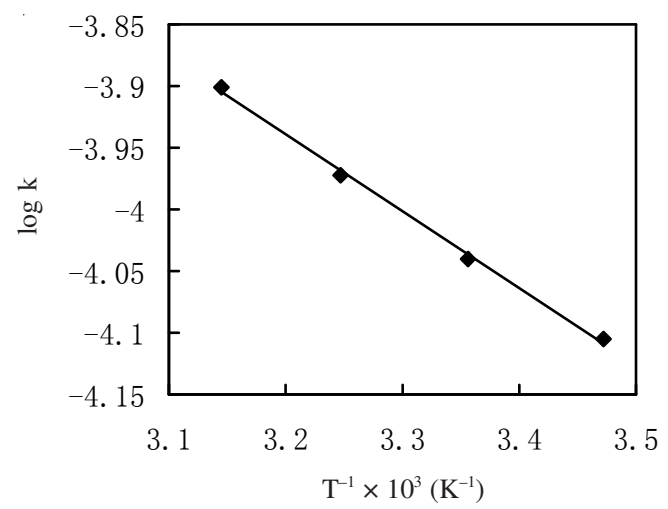

Fig. 4. Determination of activation energy of D201×4 resin for $\mathrm{Pt}$

$$
\log \mathrm{k}=-\frac{\mathrm{E}_{\mathrm{a}}}{2.303 \mathrm{RT}}+\text { constant }
$$


Thus, the apparent activation energy $\mathrm{E}_{\mathrm{a}}=-\mathrm{K}_{\text {slop }} \times 2.303 \mathrm{R}$ $=11.93 \mathrm{~kJ} / \mathrm{mol}$. Adsorption reaction with apparent activation energy less than $40 \mathrm{~kJ} / \mathrm{mol}$ is commonly named as the fast adsorption reaction, which completes easily at room temperature.

Isotherm adsorption curve: Certain amounts of the resin $(10,15,20$ and $25 \mathrm{mg})$ were weighted and put into conical flasks individually, in which $6 \mathrm{~mL}$ of the standard solution of $\mathrm{Pt}(\mathrm{IV})(2 \mathrm{mg} / \mathrm{mL})$ and $34 \mathrm{~mL}$ of buffer solution with $\mathrm{pH}=$ 3.47 were added, respectively. The experiment was carried out using the above-mentioned method at $298 \mathrm{~K}$ and when the adsorption equilibrium was reached, the equilibrium concentration $\left(\rho_{\mathrm{e}}, \mathrm{mg} / \mathrm{mL}\right)$ was determined and the corresponding adsorption capacity $(\mathrm{Q}, \mathrm{mg} / \mathrm{g})$ was calculated and plotted in Fig. 5. According to Freundlich formula $\mathrm{Q}=\mathrm{a} \rho^{1 / \mathrm{b}}$, i.e., $\log$ $\mathrm{Q}=1 / \mathrm{b}(\log \rho)+\log \mathrm{a}$, the correlation coefficient of straight line $r=0.9994$ was achieved. Thus, the slope of the straight line in Fig. 5 was $1 / b$, and $1 / b=0.107, b=9.35$. The fact that the $b$ value is between 2 and 10 indicates that $\mathrm{Pt}(\mathrm{IV})$ is easy to be absorbed ${ }^{24}$.

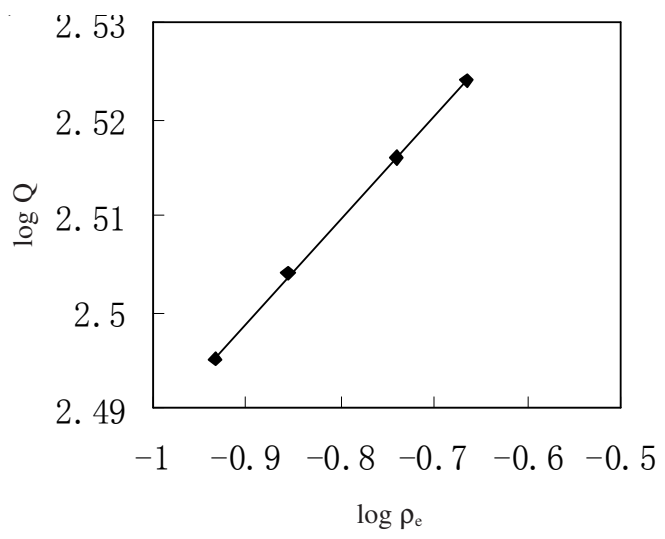

Fig. 5. Freundlich isotherm curve. $\mathrm{pH}=3.47,298 \mathrm{~K}, \rho_{0}=400 \mathrm{mg} / \mathrm{L}$

Influence of adsorption temperature on the distribution coefficient and the determination of thermodynamic parameters: $10 \mathrm{mg}$ of resin was accurately weighted. Under the experimental condition shown in Fig. 6, the distribution coefficient $\mathrm{D}$ of the resin for $\mathrm{Pt}(\mathrm{IV})$, over a range of temperature 291-318 K, was determined. $\log \mathrm{D}$ is plotted against $1 / \mathrm{T}$. The result obtained in Fig. 6 shows obviously that increasing temperature is favorable for the adsorption. It indicates that the adsorption process is an endothermic process. The correlation coefficient of straight line $r=-0.9987$ was achieved. The slope of the straight line in Fig. 6 is $\mathrm{K}_{\text {slope }}=$ $-0.0862, \mathrm{~S} / \mathrm{R}=4.1578$, according to

$$
\log \mathrm{D}=-\frac{\mathrm{H}}{2.303 \mathrm{RT}}+\frac{\mathrm{S}}{\mathrm{R}}
$$

where $\Delta \mathrm{H}=-\mathrm{K}_{\text {slope }} \times 2.303 \mathrm{R}=0.0862 \times 2.303 \times 8.314=1.65$ $\mathrm{kJ} / \mathrm{mo} 1, \Delta \mathrm{S}=4.1578 \times 8.314=34.57 \mathrm{~J} /(\mathrm{mol} \mathrm{K})$. When $\mathrm{T}=$ $298 \mathrm{~K}, \Delta \mathrm{G}=\Delta \mathrm{H}-\mathrm{T} \Delta \mathrm{S}=1.65-298 \times 0.03457=-8.65 \mathrm{~kJ} / \mathrm{mol}$.

Since $\mathrm{H}=1.65 \mathrm{~kJ} / \mathrm{mol}$ and there is less heat of adsorption, the adsorption reaction is considered to be physical adsorption.

Influence of various metal ions on the adsorption of $\mathbf{D 2 0 1} \times \mathbf{4}$ resin for $\mathbf{P t}(\mathbf{I V})$ : The results obtained are shown in

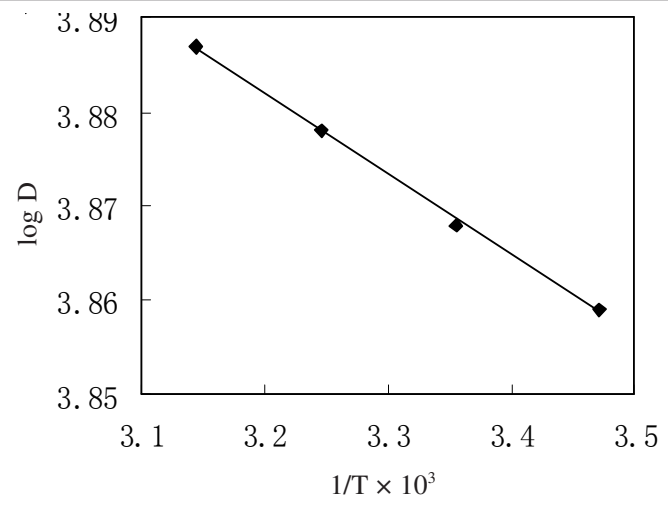

Fig. 6. Influence of temperature on distribution ratio. $\mathrm{pH}=3.47, \rho_{0}=333$ $\mathrm{mg} / \mathrm{L}$

Fig. 7. Under the condition of the same concentration of $\mathrm{Cu}$ (II), $\mathrm{Zn}(\mathrm{II}), \mathrm{Ni}$ (II), $\mathrm{Co}(\mathrm{II})$ and $\mathrm{Pt}(\mathrm{IV})$, at $\mathrm{pH}$ range of 2.63-5.73, $\mathrm{Ni}$ (II) is nearly not adsorbed and $\mathrm{Zn}$ (II), $\mathrm{Cu}$ (II), $\mathrm{Co}(\mathrm{II})$ are slightly adsorbed (the adsorption ratio is lower than $12 \%$ ); however, $\mathrm{Pt}(\mathrm{IV})$ is well adsorbed. At $\mathrm{pH}=3.47$, the adsorption ratio of $\mathrm{Pt}(\mathrm{IV})$ is $75.82 \%$. Therefore, under the condition of $\mathrm{pH}=3.47, \mathrm{Pt}(\mathrm{IV})$ can be completely separated from Ni(II) and can be well separated from $\mathrm{Zn}$ (II), $\mathrm{Cu}$ (II) and $\mathrm{Co}(\mathrm{II})$.

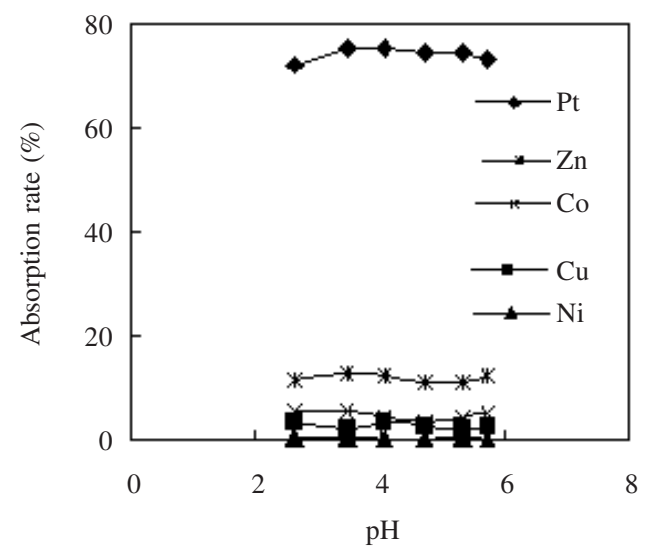

Fig. 7. Influence of various ions on the adsorption of $\mathrm{D} 201 \times 4$ resin for $\mathrm{Pt}$

\section{Determination of the complex ratio}

Equimolar method: Seven parts of different amounts of resins were accurately weighted and added into the conical flasks and then mixed with different amounts of Pt(IV). The total mole of D201×4 resin and Pt(IV) was kept as a constant at $145 \mu \mathrm{mol}$. Regardless of the molar ratio, the analysis was carried out according to the above-mentioned method. The adsorption amount versus $\mathrm{n}_{\mathrm{Pt}} /\left(\mathrm{n}_{\mathrm{Pt}}+\mathrm{n}_{\mathrm{R}}\right)$ yields a curve as shown in Fig. 8. The expected adsorption amount is the largest where the molar fraction of $\mathrm{Pt}(\mathrm{IV})$ is 0.48 . It indicates that the molar ratio of functional group to $\mathrm{Pt}(\mathrm{IV})$ is $1: 1$.

Saturated method: $30 \mathrm{mg}$ of resin was accurately weighted and under the condition of $\mathrm{T}=298 \mathrm{~K}, \rho_{0}=400$ $\mathrm{mg} / \mathrm{L}$, the experiment was carried out using the abovementioned method. The adsorption capacity of the resin for $\mathrm{Pt}(\mathrm{IV})$ is $567.5 \mathrm{mg} / \mathrm{g}$. The amount of the functional group and the capacity of the resin for $\mathrm{Pt}(\mathrm{IV})$ are calculated and shown in Table-1, which also indicates that the molar ratio of functional group to $\mathrm{Pt}(\mathrm{IV})$ is $1: 1$. 


\begin{tabular}{cccc}
\hline \multicolumn{4}{c}{ TABLE-1 } \\
& \multicolumn{3}{c}{ COMPLEX RATIO OF D201 $\times 4$ RESIN FUNCTIONAL GROUP TO Pt(IV) } \\
\hline $\mathrm{N} \%$ of D201×4 resin $(\%)$ & $\begin{array}{c}\text { Functional group capacity of } \\
\text { D201 } \times 4 \text { resin }\left(\mathrm{mmol} \mathrm{g}^{-1}\right)\end{array}$ & $\begin{array}{c}\text { Adsorption capacity of D201 } \times 4 \\
\text { resin }\left(\mathrm{mmol} \mathrm{g}^{-1}\right)\end{array}$ & $\begin{array}{c}\text { Complex molar ratio } \\
\text { FG/Pt(IV) }\end{array}$ \\
\hline 4.15 & 2.97 & 2.91 & $1.02: 1$ \\
\hline
\end{tabular}

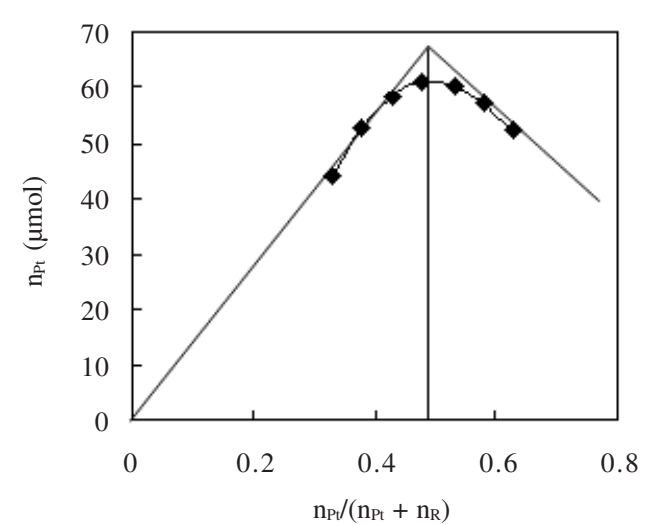

Fig. 8. Equimolar series method. $\mathrm{pH}=3.47,298 \mathrm{~K}$, total mole $145 \mu \mathrm{mol}$

Elution and recovery of platinum: The ratio of elution is shown in Table-2. The experimental result shows that the ratio of the second elution reaches more than $80 \%$ when the concentration of $\mathrm{NaOH}$ is over a range of $1.0-2.0 \mathrm{~mol} / \mathrm{L}$. Thus, $\mathrm{Pt}(\mathrm{IV})$ adsorbed on $\mathrm{D} 201 \times 4$ resin can be recovered quantitatively.

TABLE-2
ELUTION TEST OF Pt(IV)
\begin{tabular}{lcccc}
\hline Concentration of $\mathrm{NaOH}\left(\mathrm{mol} \mathrm{L}^{-1}\right)$ & 0.1 & 0.5 & 1.0 & 2.0 \\
\hline Second elution ratio $(\%)$ & 58.2 & 65.8 & 83.1 & 88.6 \\
\hline
\end{tabular}

\section{Conclusion}

Experimental results show that the static saturated adsorption capacity of $\mathrm{D} 201 \times 4$ resin for $\mathrm{Pt}(\mathrm{IV})$ is $567.5 \mathrm{mg} / \mathrm{g}$ at $\mathrm{pH}$ $=3.47$ in the medium of $\mathrm{CH}_{3} \mathrm{COOH}-\mathrm{CH}_{3} \mathrm{COONa}$. The ratio of the second elution reaches $88.6 \%$ when the concentration of $\mathrm{NaOH}$ is $2.0 \mathrm{~mol} / \mathrm{L}$. The adsorption behaviour of $\mathrm{D} 201 \times 4$ resin for $\mathrm{Pt}(\mathrm{IV})$ obeys the Freundlich isotherm and that the $\mathrm{b}$ value is between 2 and 10 indicates that $\mathrm{Pt}(\mathrm{IV})$ is easy to be absorbed. The rate constant $\mathrm{k}_{298}=9.13 \times 10^{-5} \mathrm{~s}^{-1}$. The apparent activation energy $\mathrm{E}_{\mathrm{a}}$ is $11.93 \mathrm{~kJ} / \mathrm{mol}$. The adsorption parameters of thermodynamics under $298 \mathrm{~K}$ : enthalpy change $(\Delta \mathrm{H})$
$=1.65 \mathrm{~kJ} / \mathrm{mol}$, Gibbs free energy change $(\Delta \mathrm{G})=-8.65 \mathrm{~kJ} /$ mol, entropy change $(\Delta \mathrm{S})=34.57 \mathrm{~J} /(\mathrm{mol} \mathrm{K})$. The molar ratio of functional group to $\mathrm{Pt}(\mathrm{IV})$ is $1: 1$.

\section{ACKNOWLEDGEMENTS}

The work is supported by the Special Major Science and Technology Project of Zhejiang Province, China (Project 2011C11098).

\section{REFERENCES}

1. Y.Y. Chen and X.Z. Yuan, React. Polym., 23, 165 (1994).

2. J.J. Mo and C.H. Xiong, Chin. J. Nonf. Met., 16, 924 (2006) (in Chinese).

3. S. Serrano, F. Garrido and C.G. Campbell, Geoderma, 124, 91 (2005).

4. L.M. Shi, C.H. Xiong and J.J. Mo, Chin. J. React. Polym., 12, 70 (2003).

5. C.H. Xiong and X.M. Wu, Acta Sci. Circumst., 20, 627 (2000) (in Chinese).

6. S.H. Bulbul and B. Niyaz, React. Funct. Polym., 51, 55 (2002).

7. Y.Y. Chen, C. Liang and Y. Chao, React. Polym., 36, 51 (1998).

8. C.H. Xiong and Q.X. Shen, J. Rare Earths, 20, 492 (2002).

9. B. Yang, Y.-R. Xu, Y. Dai, G.-Y. Yang and Q.-F. Hu, Asian J. Chem., 22, 2727 (2010)

10. C.H. Xiong, X.Y. Chen and C.P. Yao, Curr. Org. Chem., 16, 1942 (2012).

11. C.H. Xiong, X.Y. Chen and X.Z. Liu, Chem. Eng. J., 203, 155 (2012).

12. C.H. Xiong, C.P. Yao, L. Wang and J.J. Ke, Hydrometallurgy, 98, 318 (2009).

13. C.H. Xiong and C.P. Yao, Chem. Eng. J., 155, 844 (2009)

14. T.B. Budak, Asian J. Chem., 25, 4207 (2013).

15. M. Chamsaz and M.M. Riazi, Asian J. Chem., 24, 957 (2012).

16. C.H. Xiong, Q. Jia, X.Y. Chen, G.T. Wang and C.P. Yao, Ind. Eng. Chem. Res., 52, 4978 (2013).

17. S.Q. Cao, J.Y. Guo and L.J. Chen, Hydrometetal. Chin., 20, 195 (2001).

18. J.S. Liu, G.H. Li, H. Chen and C.P. Liu, Chin. J. Rare Met., 29, 509 (2005).

19. Z.R. Liu, J.Y. Guo and X.Y. Zhou, Shan D. Metal., 19, 25 (1997) (in Chinese).

20. C.H. Xiong and C.P. Yao, J. Hazard. Mater., 170, 1125 (2009).

21. C.H. Xiong and C.P. Yao, J. Hazard. Mater., 166, 815 (2009).

22. G.D. Brykina, T.V. Marchak and L.S. Krysina, Zh. Anal. Khim. Russ. J. Anal. Chem. (Engl. Transl.), 35, 2294 (1980).

23. G.E. Boyd, A.W. Adamson and L.S. Myers, J. Am. Chem. Soc., 69, 2836 (1947).

24. W. Kitak and R. Suzuki, In ed.: Z.L. Lu, Adsorption Basis and Design, Trans, Chemical Industry Press, Beijing (1983). 